\title{
Progress Report on the Iceland Deep Drilling Project (IDDP)
}

by Gudmundur O. Fridleifsson and Wilfred A. Elders

\section{Introduction}

The Iceland Deep Drilling Project (IDDP) is a project of "Deep Vision", a consortium of the government and the three leading energy companies in Iceland. It aims to improve the economics of geothermal energy production by exploring for supercritical hydrothermal fluids as a possible energy source. This will require drilling to depths of 4 to $5 \mathrm{~km}$ in order to reach temperatures of $400^{\circ} \mathrm{C}-600^{\circ} \mathrm{C}$. From the outset, Deep Vision, recognizing that a broad scale of studies would be necessary in order to explore the little understood supercritical environment, welcomed the inclusion of basic scientific studies in the IDDP and invited participation from the international scientific community, to the mutual advantage of both industrial and scientific participants (Fridleifsson and Albertsson, 2000). The guiding principle was that the incremental costs of drilling and sampling for the science program, and their subsequent study, should be provided by the scientific community. Two planning workshops funded by the International Continental Scientific Drilling Program (ICDP) were held in 2002, and a two-yearlong feasibility study funded by Deep Vision was concluded in 2003 (Fridleifsson et al., 2003). Modeling indicates that if well-head enthalpy is to exceed that of conventionally produced geothermal steam, the reservoir temperature must exceed $450^{\circ} \mathrm{C}$. Producing high-enthalpy steam from a well penetrating a reservoir $>450^{\circ} \mathrm{C}$ at a rate of $0.67 \mathrm{~m}^{3} \mathrm{~s}^{-1}$ would

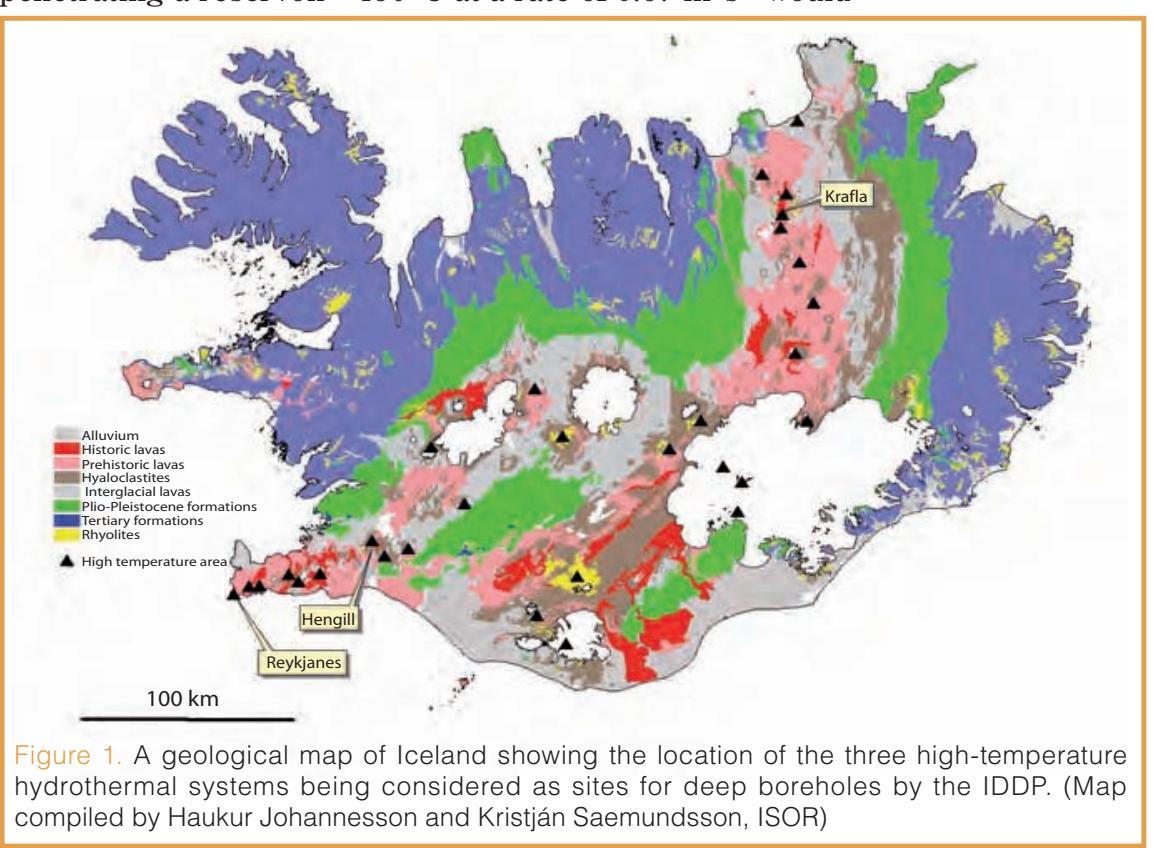

be enough to generate $40-50 \mathrm{MW}$ of electricity. This is an order of magnitude greater than the power produced by existing geothermal wellsin Iceland. Threehigh-temperature geothermal fields, at Reykjanes, Hengill, and Krafla, were selected as sites for deep drilling (Fig. 1). In late 2003 a member of the consortium offered one of its planned exploratory wells located on the Reykjanes peninsula for deepening by the IDDP (Fridleifsson and Elders, 2005). It was completed at $3.1 \mathrm{~km}$ depth in February 2005; however, this well of opportunity became blocked during a flow test in November 2005. After subsequent attempts at reconditioning failed, it was decided in February 2006 to abandon the hole, requiring a change in the IDDP work plan.

In June 2006, after careful consideration of all of the options available, Deep Vision decided to move operations to Krafla, the northernmost of the high-temperature areas (Fig. 1) as the site for the first deep IDDP borehole. This location is within a volcanic caldera with higher temperature gradients and more recent volcanic activity than Reykjanes (Fig. 2). The IDDP plan is to rotary drill and spot core this hole to $3.5 \mathrm{~km}$ depth and subsequently deepen it to $4-5 \mathrm{~km}$ using continuous wireline coring for scientific purposes, and then attempt a flow test from the deepest portion of the well. This plan is a compromise between the desire to obtain as much drill core as possible and technical and budgetary limitations.

\section{Need for Coring}

The study of the coupling of the chemical and mineral alteration, fracture propagation, pressure solution, and fluid flow will be based on analysis of data on mineral chemistry, isotopes, geothermometry, and fracture geometry. Without drill cores, it is impossible to unravel the nature and chronology of fracture failure and vein infilling, to detect time serial fracture events, to determine constitutive rock properties, and to understand the nature and formation of permeability. Measurements of mechanical and thermal properties of core as a function of temperature are necessary to quantify processes related to brittleductile behavior. The permeability and thermal diffusivity of fractured and intact, 


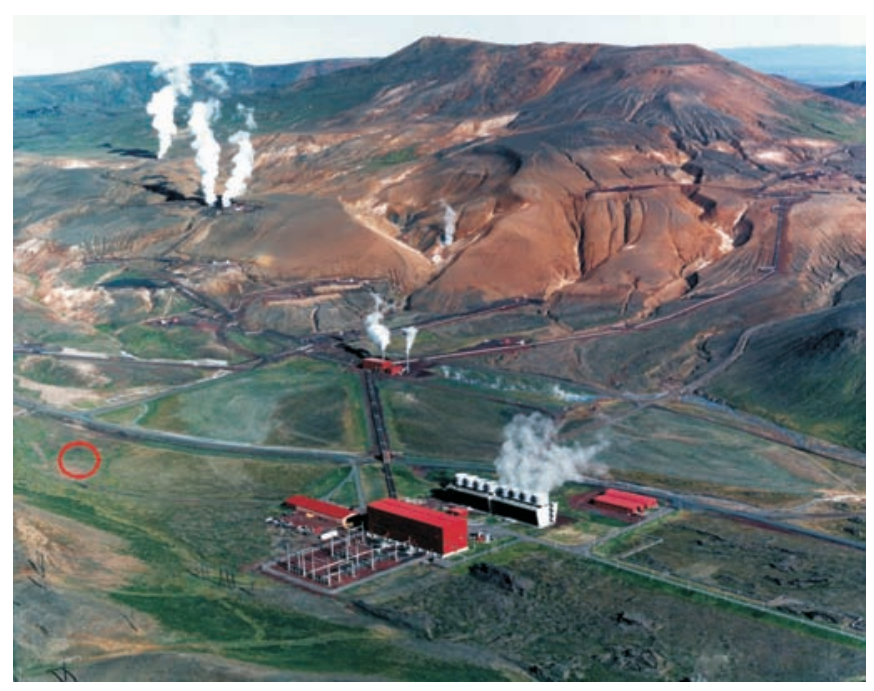

Figure 2. A view to the Krafla Central Volcano. A $60 \mathrm{MW}$ power plant is seen in the foreground. The red circle denotes the potential IDDP drill site (Photo by Emil Thor, Iceland).

fresh and altered, basalt comprise essential baseline information for fluid circulation models. There are also practical reasons for coring. Lost circulation during drilling, which is common in highly permeable zones in Iceland, would prevent recovery of drill cuttings. Similarly, the use of borehole televiewers and most other logging tools is impossible because of high temperatures. Recognizing when the supercritical conditions are reached during drilling will best be done by studying mineral assemblages and fluid inclusions in cores as they are recovered. However, because continuous coring is slower and therefore more expensive than conventional drilling, it was decided to reserve continuous coring for the supercritical zone and to take only spot cores in the upper part of the well. In the event of total loss of circulation, it may be possible to use special downhole logging tools rated up to $300^{\circ} \mathrm{C}$, by sufficient cooling of the well down to the feed point. However, when downhole logging is not possible and there is loss of circulation and no return of drill cuttings in the supercritical zone, the only alternative is to obtain drill cores from these zones of greatest interest.

In addition to exploring for new sources of energy, the IDDP project will provide the first opportunity worldwide for scientists to investigate the deep, high temperature reaction zone of a mid-ocean ridge hydrothermal system that reaches supercritical conditions, with amphibolite facies grade of metamorphism $\left(>400^{\circ} \mathrm{C}\right)$. The drill site is ideally situated for a broad array of scientific studies involving water/rock reactions at extremely high temperatures in active setting. Active processes in such deep high-temperature reaction zones that control fluid compositions have never before been available for comprehensive direct study and sampling.

In autumn 2006 tenders were solicited for casings and valves for the proposed well, as well as pre-qualification documents for drilling contractors. Given the competitive market situation for drilling rigs, and associated year-long lead times in obtaining well completion materials, we anticipate that drilling will not start before spring 2008. It should take about four months to reach $3.5 \mathrm{~km}$ depth, including about two weeks for spot coring. Deep Vision will pay for drilling and completing the well, but the spot coring will be funded by ICDP and the U.S. National Science Foundation (NSF). Deepening the well to about $4.5 \mathrm{~km}$ depth will take an additional two to three months with continuous wireline coring, with the incremental costs of coring being substantially funded by ICDP and NSF. The drilling went out for international bidding in December 2006, and a contract is expected to be signed in early 2007 for drilling and casing the well to $3500 \mathrm{~m}$ in 2008 . Depending on logistics and progress within the first phase, the continuous coring phase may have to be deferred to 2009 .

\section{Predicting P-T Conditions in the Krafla Well}

The features of paramount importance related to the drilling of the IDDP well are (1) the presence, size, and specific location of a magma chamber previously interpreted to exist

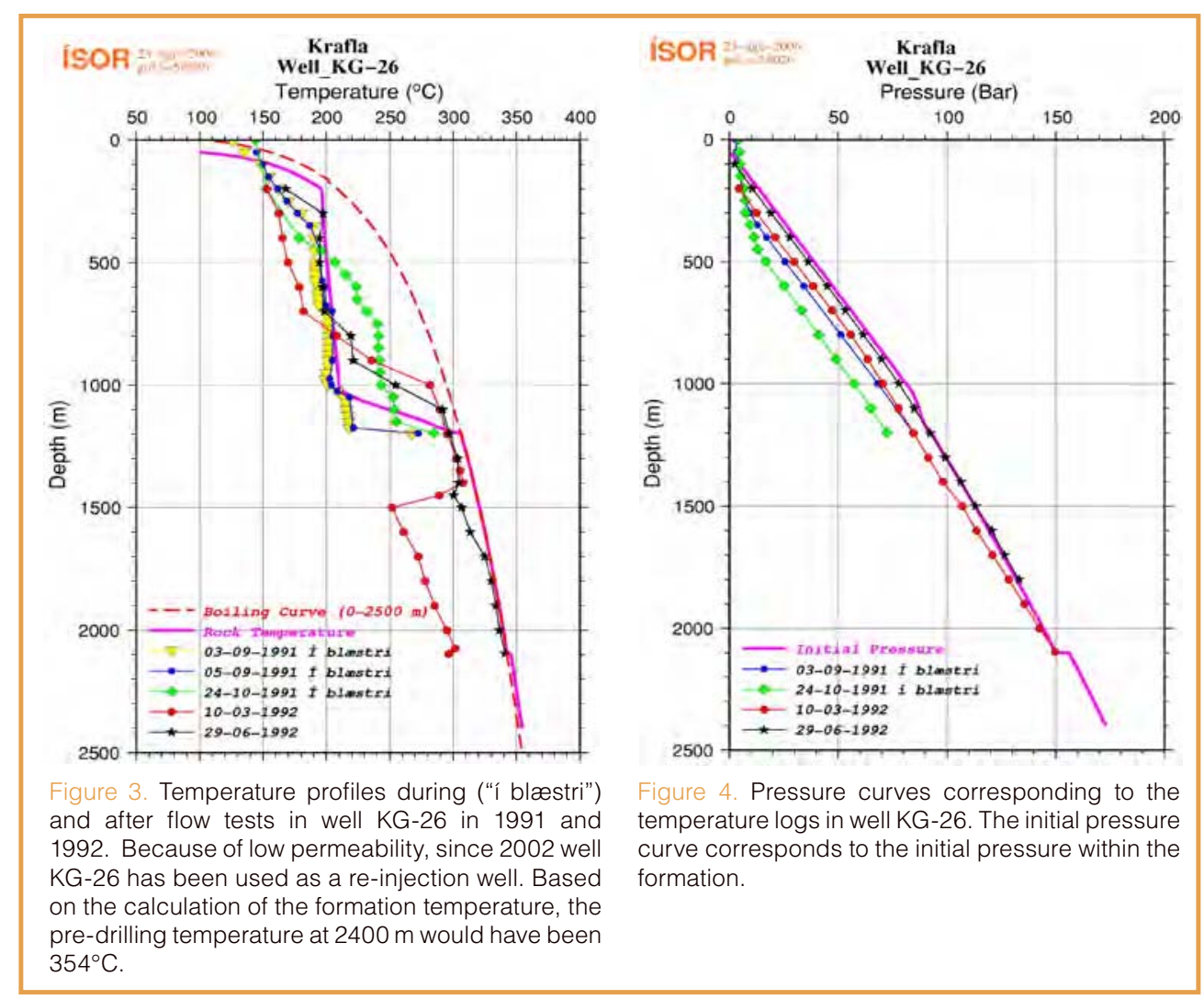




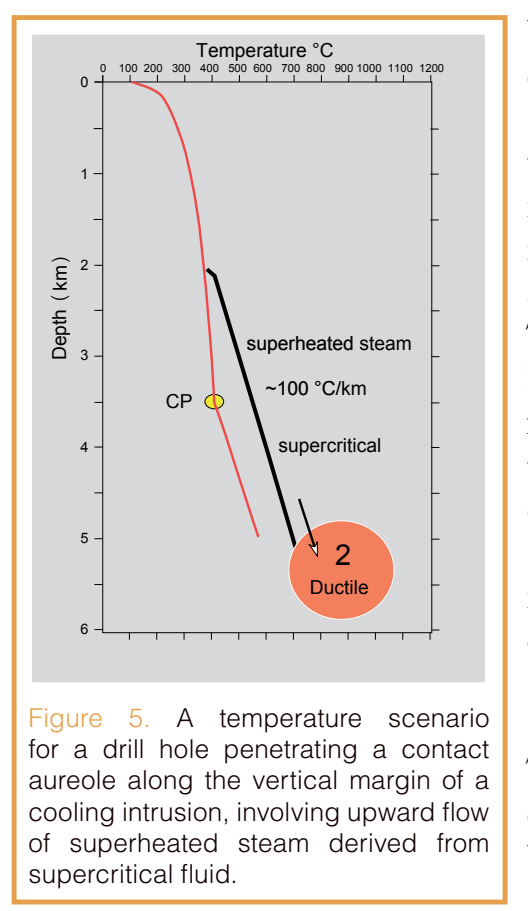

beneath the Krafla caldera, (2) the pressure-temperatureconditions within the geothermal field, and (3) the nature of permeability at depth at the drill site. The magma chamber in Krafla was inferred from S-wave attenuation during the volcanic eruptions at Krafla in 1975-1984, and it was interpreted to be at 4-8 km depth below the drill field (Einarsson 1978; Björnsson, 1985). The current thermal conditions within this body are not known. One of the aims of the

IDDP at Krafla is to drill into the seismogenic zone at $4-5 \mathrm{~km}$ depth to determine if the formation of natural fractures at high temperatures generates permeability and to test the hypothesis that the base of the upper crustal seismogenic zone marks the transition from brittle to ductile behavior.

At Krafla plans are underway to expand production from $60 \mathrm{MW}$ to $100 \mathrm{MW}$ electricity. A recent report on the geothermal conditions at Krafla is available at the IDDP website (http://www.iddp.is), and this report is partly based on earlier reports on Krafla (Ármannsson et al., 1987, 1993; Björnsson and Steingrímsson, 1991; Gudmundsson, 2001). Well KG-26 is at about $300 \mathrm{~m}$ distance from the site selected for the IDDP well, and we expect P-T conditions to be similar. Figures 3 and 4 show temperature $(\mathrm{T})$ and pressure $(\mathrm{P})$ profiles from Well KG-26. These data show that conditions should follow the boiling-point-with-depth curve (BPDcurve) in the IDDP well from $1100 \mathrm{~m}$ depth downwards. For pure water the critical point would be reached at about $3.5 \mathrm{~km}$ depth, but for the geothermal fluids at Krafla (which have a TDS of $1000-2000 \mathrm{mg} \mathrm{kg}^{-1}$ ) it could be somewhat deeper. The plan is to cement the third and last intermediate casing to $\sim 3.5 \mathrm{~km}$ depth in the first phase of the IDDP well. Thus, supercritical conditions should be reached soon after drilling out of the $3.5 \mathrm{~km}$ deep casing. However, the possibility of reaching temperature conditions higher than that controlled by the BPD-curve at shallower depth also needs to be considered. For instance, the temperatures below $2200 \mathrm{~m}$ depth in Well NJ-11 at Nesjavellir in 1985 (Steingrímsson, et al., 1990) certainly surpassed the conditions determined by the BPD-curve and involved at least superheated steam hotter than $>380^{\circ} \mathrm{C}$. Therefore, during drilling of the IDDP well at Krafla, we also need be prepared for P-T conditions surpassing the BPD-curve. One such a scenario is shown in Figure 5 (from Fridleifsson et al., 2003).

\section{Site Location}

The proposed location of the IDDP drill hole is close to the inferred southern margin of the magma chamber at $4-8 \mathrm{~km}$ depth. This site was selected in order not to intersect the hot magma body directly, where permeability could be absent, but rather to contact the permeable fluid heat exchange system at depth that surrounds it. We expect the P-T conditions would follow a path similar to that outlined in Fig. 6a. If, on the other hand, the IDDP borehole is too close to a cooling magma chamber, it could bottom in dry and ductile rock, a scenario shown in Figure 6b. This was the case in the 3.7-km-deep exploratory borehole at Kakkonda, in the Hachimanti Geothermal Field, Iwate Prefecture, Japan (Muraoka et al., 1998). That borehole penetrated into a neogranitic pluton (tonalite with a K-Ar age of $0.19 \mathrm{Ma}$ ), a cooling granitic intrusion that is the heat source for the hydrothermal system. The shallow hydrothermal system exhibited a BPD-curve controlled temperature profile down to $3100 \mathrm{~m}$ depth, where a $380^{\circ} \mathrm{C}$ temperature was recorded and a transition from brittle to ductile conditions was observed. Temperatures reached $>500^{\circ} \mathrm{C}$ at $3729 \mathrm{~m}$ (Muraoka et al., 1998). At the bottom of the borehole the permeability was very low and the borehole was subject to plastic deformation. For this reason the Kakkonda borehole was completed as a production well in the shallow hydrothermal system.

The design of the IDDP drill hole should be capable of handling both conditions outlined in Figures 5 and 6 . For the well to be economically successful, in addition to reaching supercritical P-T conditions, good permeability is also necessary. Permeable structures, like major fractures channeling fluids from deeper heating zones, are needed. According to the IDDP feasibility report and references therein, such structures should exist within the Krafla geothermal field at depth. The drill site chosen was selected to optimize inter-

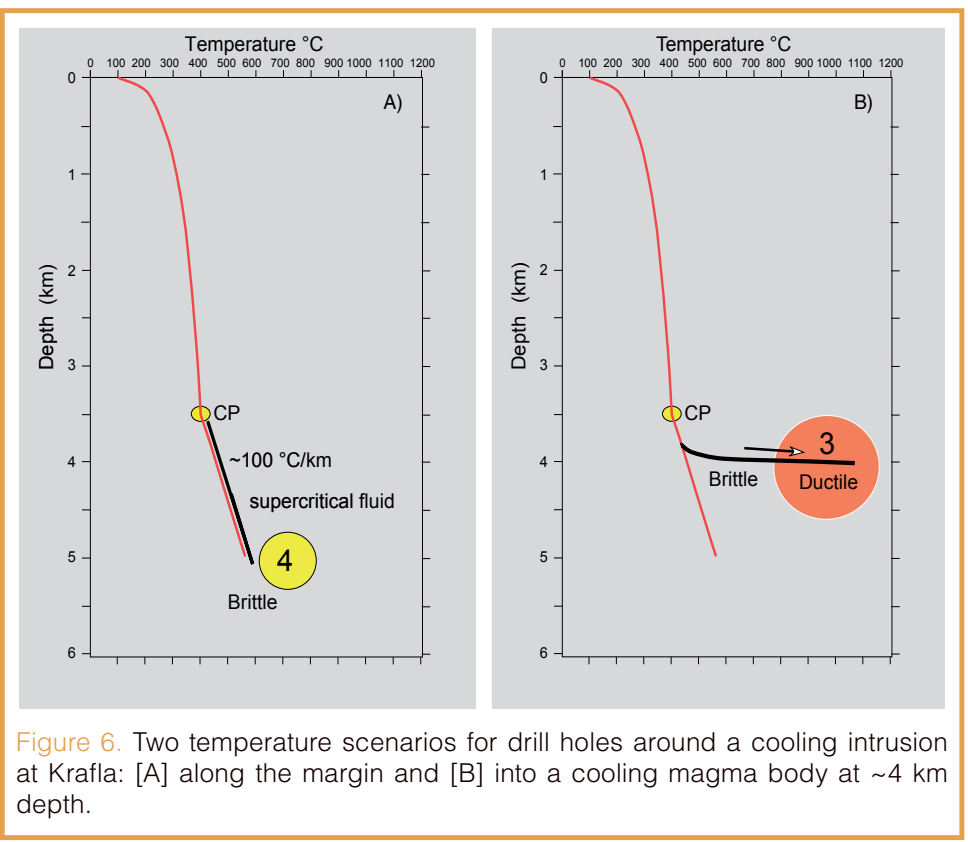


cepting potential fractures at depths. If the drill hole intercepts a major permeable fracture at shallower depth (e.g., between 2.4 and $3.5 \mathrm{~km}$ ) that produces superheated steampossibly at $500^{\circ} \mathrm{C}$-derived from supercritical fluid at greater depths, efforts will be made to study it thoroughly before casing it off.

\section{Expected Lithologies, Hydrothermal Alteration and Fluid Chemistry}

Assuming that conditions will be similar to those found in Well KG-26, the expected hydrothermal conditions in the first 2500 meters of IDDP drill hole, there should be an upper system characterized by an isothermal fluid system at $200^{\circ} \mathrm{C}$ at about 200-1100 $\mathrm{m}$ depth, and a lower system following the BPD-curve between 1100 and $2500 \mathrm{~m}$ depth. These systems will be separated in the borehole behind cemented casings. The uppermost kilometer of the Well KG-26 penetrated two major hyaloclastite units separated by lava succession. Below $1 \mathrm{~km}$ depth a dense intrusive rock complex is expected, including felsic intrusive rocks at close to $2 \mathrm{~km}$ depth. Some of the intrusive rock contacts could involve reasonable sized feed points. If P-T conditions are similar to those in well $\mathrm{KG}-26$, and if feed points occur at about $2.4 \mathrm{~km}$ depth, temperatures of $>350^{\circ} \mathrm{C}$ and static pressure of about 180 bar can be expected at $2.5 \mathrm{~km}$ depth. Predicting the likely situation below $2.5 \mathrm{~km}$ depth is more difficult, and two different scenarios are envisaged. The most likely situation would be that P-T conditions follow the BPD-curve to about $3.5 \mathrm{~km}$ depth. On the other hand, if there is good vertical permeability, superheated steam could flow readily between depths of 2.5 and $3.5 \mathrm{~km}$.

The fluids in the Krafla system are dilute (TDS 1000-2000 mg kg-1), similar to those at Nesjavellir (TDS $1000-2000 \mathrm{mg} \mathrm{kg}^{-1}$ ), whereas in Reykjanes salinity is close to that of seawater (TDS 30,000-35,000 $\mathrm{mg} \mathrm{kg}^{-1}$ ). The present Krafla fluid is in all respects good for production and is not likely to cause problems. During the eruptions of 1975-84, the $\mathrm{CO}_{2} / \mathrm{H}_{2} \mathrm{~S}$ ratios in some geothermal wells at Krafla had a high magmatic component; however, gas compositions have returned to values similar to those obtained before the Krafla eruptions, including the values found for the upper and lower parts of KG-26. Exactly what the fluid composition will be like below $2.4 \mathrm{~km}$ depth in Krafla remains to be observedan integral part of the IDDP project.

\section{Acknowledgements}

We thank the Deep Vision consortium for inviting us to organize a science program within the framework of its efforts to augment geothermal resources. We are also grateful for financial support from the International Continental Scientific Drilling Program and the US National Science Foundation (award number EAR-0507625 to W.A. Elders).

\section{References}

Armannsson, H., Gudmundsson A., and Steingrimsson, B., 1987. Exploration and development of the Krafla geothermal area. Jokull, 37:13-30.

Armannson, H., Björnsson, G., and Guðmundsson, Á, 1993. Krafla Well KG-26. Recovery and flow test. Orkustofnun Report OS93033/JHD-16 B. Reykjavik, Iceland, 35 p. (in Icelandic).

Björnsson, A., 1985. Dynamics of crustal rifting in NE- Iceland. Geophysics, 90:151-162.

Björnsson, G., and Steingrímsson, B., 1991. Krafla - Well KG-26. Evaluation of its initial conditions and productivity. Orkustofnun Progress Report 91/07. Reykjavik, Iceland, 10 p. (in Icelandic).

Einarsson, P., 1978. S-wave shadows in the Krafla caldera in NEIceland, evidence for a magma chamber in the crust. Bull. Volcanol. 41:1-9.

Fridleifsson, G.O., and Albertsson, A., 2000. Deep geothermal drilling at Reykjanes Ridge: opportunity for an international collaboration. In Proceedings of the World Geothermal Congress 2000, Japan: Reykjavik, Iceland (International Geothermal Association, Inc.), 3701-3706.

Fridleifsson, G.O., Ármannsson, H., Árnason, K., Bjarnason, I. P., and Gíslason, G., 2003. Part I : Geosciences and site selection. In Fridleifsson, G.O. (Ed.), Iceland Deep Drilling Project, Feasibility Report. Orkustofnun Report OS-2003-007, Reykjavik, Iceland, $104 \mathrm{p}$.

Fridleifsson, G.O., and Elders, W.A., 2005. The Iceland Deep Drilling Project: a search for deep unconventional geothermal resources. Geothermics, 34:269-285. doi:10.1016/j.geothermics.2004.11.004

Gudmundsson, A., 2001. An expansion of the Krafla Power Plant from 30 to 60 MWe Geothermal Consideration. GRC-Trans.25:741-746.

Muraoka, H., Uchida, T., Sasada, M., Mashiko, Y., Akaku, K., Sasaki, M., Yasukawa, K., Miyazaki, S., Doi, N., Saito, S., Sato, K., and Tanaka, S., 1998. Deep geothermal resources survey program: igneous, metamorphic and hydrothermal processes in a well encountering $500{ }^{\circ} \mathrm{C}$ at $3729 \mathrm{~m}$ depth, Kakkonda, Japan. Geothermics, 27 (5/6):507-534. doi:10.1016/S0375-6505(98)00031-5

Steingrímsson, B., Gudmundsson, Á., Franzson, H., and Gunnlaugsson, E., 1990. Evidence of supercritical fluid at depth in the Nesjavellir field. In Proceedings of the Fifteenth Workshop on Geothermal Reservoir Engineering. Stanford University, Calif., U.S.A., SGP-TR_130, pp. 81-88.

\section{Authors}

Gudmundur O. Fridleifsson, ISOR, Iceland GeoSurvey, Grensasvegur 9, IS-108, Reykjavik, Iceland., e-mail: gof@ isor.is

Wilfred A. Elders, Department of Earth Sciences, University of California, Riverside, Calif. 92521, U.S.A.

\section{Related Web Link}

http://www.iddp.is 